\title{
Administrative Organization and Financial Support of Land-Grant College and University Libraries
}

\author{
Dr. McCarthy is director, Cornell Uni- \\ versity Library.
}

$\mathrm{I}^{\mathrm{N}}$

THE summer of 1947 , in preparing for a survey of the libraries of Cornell University, a questionnaire was distributed to fifty-two land-grant colleges and universities, requesting information on the administrative organization of agricultural college libraries, and statistical data on library support, book collections, and staff. The replies which could be used numbered forty for most of the questions, except those calling for financial data, in which it was apparent that the base of reporting varied so widely as to make the returns of little value for comparative study.

Summarizing the replies dealing with organizational problems, it may be observed that the agricultural college is not usually an autonomous institution, that it is normally situated in the same vicinity as the parent institution, and that the agricultural college library is ordinarily organized as part of the main library. Replies to subsequent questions indicate that in most cases there is no separate agricultural experiment station library, and materials purchased on experiment station funds are normally considered a part of the agricultural college library.

Ordinarily the book collections of the agricultural college libraries are recorded in the main library catalog, there being only two instances in which this is not the case. It is also true that the holdings of agricultural experiment station libraries are commonly recorded in the main library catalog, although there are six instances in which this is not the case. The catalog records for agricultural library books included in the main library catalog cover all entries in thirty-one institutions; in four institutions they include author entries only; and in two institutions they include author and subject entries but omit certain secondary entries. With regard to serials it may be noted that all but three of the forty institutions replying to the question concerning serial records do maintain a central record of all serials received by all libraries of the institution.

It is common in most land-grant institutions for the main library to do the work of acquistion, cataloging, and binding for the agricultural library. To the question "Are acquisition, cataloging, binding, and photographic activities for the agricultural library carried on by the main library?" there were thirty-nine answers. In twentythree instances it was stated that all of these activities were carried on by the main library; in two it was indicated that none of these activities was carried on by the main library; and in nine institutions all of the activities except photographic service were provided by the main library. In the remaining five institutions, there was some division of work of acquisition, cataloging or 
binding, between the main library and the agricultural college library.

The exchange situation of most landgrant institutions is a favorable one, since thirty-one institutions indicated that agricultural college publications are available to the main library for exchange, and only two institutions indicated that they are not so available. Twelve institutions including, of course, many of those in which agricultural college publications are available to the main library for exchange, indicated that these publications are also furnished to the agricultural library and to the agricultural experiment station library for exchange purposes. The situation with regard to the publications of agricultural experiment stations is almost exactly the same, except that the number of institutions in which these publications are furnished to the main library is thirty-five rather than thirty-one, and the number in which they are not available to the main library is two.

The campuses of many of the land-grant institutions are rather large and it is natural to find departmental libraries in various agricultural fields. The question on this topic was answered by forty institutions, of which twenty-five indicated that they maintain such departmental libraries, and fifteen indicated that they do not. The administration of these departmental libraries presents a somewhat less clear picture, although it is apparent that central administration is to be found in the majority of them. In seventeen institutions such departmental libraries are a part of the main library system; in four institutions such departmental libraries are a subdivision of the agriculture library; and in seven institutions some or all of these departmental libraries are operated independently of the library system under the control of instructional departments. The financial support of these libraries also presents a somewhat mixed pic- ture. 'There were forty-one replies to the question concerning financial support of departmental libraries and they indicate that, while in a fair number of instances the full support of these libraries is provided on the library budget, there are a number of instances in which some or all of the support is drawn from the instructional departments. In eleven institutions the salaries are carried as part of the main library budget, in two they are a part of the agriculture library budget, and in eight they are a part of the budget of instructional departments. As regards book funds: in fifteen institutions they are included in the main library budget, in two they are a part of the agriculture library budget and in thirteen they are a part of the department budget. It is obvious, of course, that in a number of instances book funds may be supplied both by the department and the library. In a few instances this is true of salaries as well.

The question concerning the availability of photographic equipment was answered by thirty-seven libraries of which twenty-four are prepared to furnish photographic reproductions of their materials. Only seventeen of the thirty-seven who answered this question indicated the location of the facility, but of the seventeen, eleven depended on a general campus photographic service rather than on a separate library photographic service. Of the twenty-four institutions which indicated the types of photographic reproduction they could provide, fourteen are prepared to supply both microfilm and photostat, eight can supply only photostat, and two can supply only microfilm.

In studying the question of library support an attempt was first made to apply to Cornell the minimum standards of the A.L.A. for institutions of higher education. After some tentative figures had been worked out, the A.L.A. minimum standards 
were discarded as being an inadequate measure of the library needs of the university.

A measure of adequacy of support which frequently has been used in the past is that of $\$ 25$ per student. Since the A.L.A. recommended in 1946 that library budgets be increased 50 per cent, in order to maintain the same standards as in 1940, it would seem to be correct to say that this figure should now be $\$ 37.50$ per student. If this figure were applied to Cornell, with its present enrolment, it would result in a library budget of approximately the amount that was expended in $1947-48$, yet there is general agreement that library funds are inadequate, and that many necessary and desirable services are not being provided. Actually the budget recommended by the surveyors in their report approximates $\$ 50.00$ per student rather than $\$ 37.50$.

A third measure of adequacy of library budget support is the ratio of library expenditures to total university expenditures for educational and general purposes. The percentage commonly considered necessary for adequate library support has been from 4 to 5 per cent, or, in any case, not less than 4 per cent. The annual library budget recommended by the surveyors for Cornell would be approximately 3.5 per cent of the current year's university expenditures for educational and general purposes.

In working out the various tables included in the survey report and as a result of the unsuccessful attempt to produce a significant comparative table on the financial support of the agricultural libraries, a table was compiled from various published sources, principally the statistical tables published in the July 1947 College and $R e$ search Libraries and the printed financial reports of various land-grant institutions, which would show both expenditures per student and the ratio of library expenditures to total educational expenditures for land- grant college libraries as a whole, instead of for the agricultural libraries only. The results of this compilation are presented in Table I.

Among these institutions, the per student library expenditure ranges from a low of $\$ 2.67$ to a high of $\$ 51.12$. The average is $\$ 22.28$ and the median is $\$ 20.75$. The nineteen institutions included in the table may not be representative of the entire group of land-grant institutions and it is possible that a selection of another group of nineteen land-grant institutions could show either a better or a poorer picture, but the data reported are, nevertheless, indicative of the kind of support which is being provided in many of the land-grant institutions. The per student expenditure in 1945-46 was still, on the average, below the minimum considered essential in the 1930's, and of course, still farther below the revised minimum of $\$ 37.50$. If, as is apparent at Cornell, an expenditure of approximately $\$ 50.00$ per student is necessary, the average per student expenditure of $\$ \mathbf{2 2 . 2 8}$ is seen to be seriously inadequate.

Turning from per student expenditure to the ratio between library expenditures and total educational expenditures of the same nineteen institutions, it is apparent that there is again a wide spread between the high point and the low. The institution at the top of the scale had a ratio of 9.3 per cent, while the institution at the lowest point of the scale had a ratio of I.I 4 per cent. The average ratio was 2.77 per cent and the median was 2.31 per cent.

For comparative purposes the figures for these same nineteen institutions in 1928 , as reported in the land-grant college survey of 1930, and for 1937, have been examined. The data, in terms of averages, medians and ranges, for the three years are given in Table II, "Library Expenditures Per Student," and Table III, "Ratio of Library 
Table I

Library Expenditures Per Student and Ratio of Library Expenditures to Total Institutional Expenditures for Certain Institutions, 1945-46

\begin{tabular}{|c|c|c|c|c|c|}
\hline Institution & Enrolment & $\begin{array}{c}\text { Library } \\
\text { Expenditure }\end{array}$ & $\begin{array}{c}\text { Per Student } \\
\text { Library } \\
\text { Expenditure }\end{array}$ & $\begin{array}{c}\text { University } \\
\text { Expenditure }\end{array}$ & $\begin{array}{c}\text { Ratio of Library } \\
\text { Expenditure to } \\
\text { Total University } \\
\text { Expenditure } \\
\text { (Per Cent) }\end{array}$ \\
\hline Arizona & 4,100 & $\$ 49,298.00$ & $\$ 12.02$ & $\$ 1,834,370.00$ & 2.68 \\
\hline California & 21,425 & $802,813.00$ & $37 \cdot 46$ & $38,558,077.00$ & 2.08 \\
\hline Connecticut & 8,000 & $21,423.87$ & 2.67 & $1,877,361.00$ & 1.14 \\
\hline Cornell & 7,928 & $179,203.00$ & 22.60 & I $3,250,398.00$ & 1.35 \\
\hline Georgia & 2,593 & $132,662.00$ & 51.12 & I,420,401.co & $9 \cdot 33$ \\
\hline Illinois & I 5,989 & 6 I 8,020.1 I & 38.65 & 14,6 I $6,222.00$ & 4.22 \\
\hline Iowa State & 7,978 & I $65,464.00$ & 20.74 & $6,181,345.00$ & 2.67 \\
\hline Louisiana State & 7,351 & $210,313.28$ & $28.6 \mathrm{I}$ & $5,687,414.00$ & 3.69 \\
\hline Maine & $\mathbf{I}, 792$ & $28,524.86$ & 15.91 & $1,620,442.47$ & 1.76 \\
\hline M.I.T. & 4,500 & $93,444.86$ & 20.76 & $4,176,498.00$ & 2.23 \\
\hline Minnesota & 18,594 & $405,605.00$ & $21.8 \mathrm{I}$ & $12,910,939.00$ & 3.14 \\
\hline Nebraska & 6,675 & I I 7,64 I I 9 & 17.62 & $5,079,634.00$ & 2.31 \\
\hline New Hampshire & 3,200 & $44,383.00$ & 13.86 & $1,902,961.00$ & 2.33 \\
\hline Rutgers & 3,679 & $106,978.89$ & 29.07 & $5,648,06$ r.00 & 1.89 \\
\hline Ohio State & 16,000 & $254,498.86$ & 15.90 & $11,038.814 .00$ & 2.30 \\
\hline Oregon State & 5,924 & $101,349.00$ & 17.10 & $3,156,034.00$ & 3.21 \\
\hline Penn State & 6,800 & $146,387.00$ & 21.52 & $8,816,387.00$ & 1.66 \\
\hline Wisconsin & 13,476 & $203,465.01$ & 15.09 & I 1 , 7 1 $0,468.00$ & 1.73 \\
\hline Wyoming & 1,873 & $38,922.00$ & 20.78 & $1,289,519.00$ & 3.01 \\
\hline
\end{tabular}

Expenditures to Total Educational Ex- in 1945-46. (Table II) The ratio of lipenditures."

In the eighteen year period from 1926 through $1945-46$, the average expenditures per student have increased from $\$ 16.00$ in 1928 to $\$ 19.38$ in 1937 and on to $\$ 22.28$ brary expenditure to total educational expenditures increased from 2.52 per cent in 1928 to 2.996 per cent in 1937 and then slipped back to 2.77 per cent in 1945-46. (Table III) For these nineteen institu-

Table II

Library Expenditures Per Student in Nineteen Selected Land-Grant College Libraries in 1928, 1937, and 1945/46

\begin{tabular}{lccc}
\hline & 1928 & 1937 & $1945 / 46$ \\
\hline Average Expenditure Per Student & $\$ 16.00$ & $\$ 19.38$ & $\$ 22.28$ \\
Median Expenditure Per Student & 15.00 & 17.65 & 20.76 \\
Range of Per Student Expenditure & $7.00-\$ 27.00$ & $10.85-\$ 42.35$ & $2.67-\$ 51.12$ \\
\hline
\end{tabular}

\section{Table III}

Ratio of Library Expenditures to Total Educational Expenditures in Nineteen Selected Land-Grant College Libraries in 1928, 1937, and 1945/46

\begin{tabular}{llll}
\hline & 1928 & 1937 & $1945 / 46$ \\
\hline Average Ratio & 2.52 & 2.996 & 2.77 \\
Median Ratio & 2.6 & 2.94 & 2.31 \\
Range & $.8-5.2$ & $1.54-4.92$ & $1.14-9.33$ \\
\hline
\end{tabular}


tions there has been an increase of $\$ 6.28$ per student expenditure for library purposes in the eighteen year period, and the average ratio of library to total university expenditures has increased from 2.52 to 2.77 per cent. If however, the decreased purchasing power of the dollar is considered, it seems doubtful that there has been any significant improvement.

When these averages are compared with the commonly used standards of $\$ 25.00$, now increased to $\$ 37.50$, per student and 4 to 5 per cent of the total institutional expenditures, one can have his choice of conclusions: either the library situation in most land-grant colleges is very bad; or, the standards are higher than they should be. It may be argued that setting the minimum at 4 per cent creates an objective at which institutions should continue to aim even though, if past experience is a guide, they can never expect to achieve it. On the other hand, it may be argued that landgrant colleges, which do not offer a full university program, may not require the 4 per cent ratio. It is not inconceivable that a lower expenditure per student and a lower ratio than the one that has been commonly used may serve to provide adequate library services and facilities in institutions confined to technical programs of instruction and research.

In any case, it seems clear that the two standards: per student expenditure, and ratio of library expenditures to total expenditures, should be worked out so that there is a significant relationship between them. As things now stand, if we say the per student expenditure should be $\$ 37.50$ we are in effect saying that for an institution such as Cornell a library budget of approximately $\$ 400,000.00$ will meet the minimum standards. This would mean a ratio of approximately 2.75 per cent. However, if we say, as we have been saying, that the ratio should be 4 per cent, the recommended library budget would be approximately $\$ 600,000.00$ or $\$ 57.00$ per student.

\section{Library Service to Technical Agriculturists}

\section{(Continued from page 326)}

underlying sciences whether from his own library shelves, or those of the U. S. Department of Agriculture Library, the $\mathrm{Li}$ brary of Congress, the University of California, or any other library. The technical agriculturist serves the world's oldest and most basic industry - an industry as old as the Garden of Eden. His responsibility is great. In supplying the tools with which the technical agriculturist works, the agricultural librarian also has a great responsibility. He provides the best and most upto-date material that his funds or his borrowing power can obtain; he searches the literature of the past to aid in solving the problems of the present and the future; and he does both with efficiency and dispatch, keen intelligence, and sympathetic interest. 